\title{
$\beta$-Glucuronidase Activity in Fibroblasts Cultured from Persons with and without Cystic Fibrosis*
}

\author{
SHIRLEY B. RUSSELL, † JAMES D. RUSSELL, † and JOHN W. LITTLEFIELD
}

\author{
From the Genetics Unit, Children's Service, Massachusetts General Hospital and the Department of Pediatrics, \\ Harvard Medical School, Boston, Massachusetts, USA
}

A decrease has been reported in the $\beta$-glucuronidase activity of epidermis and sweat glands of persons with cystic fibrosis, in comparison with the activity in these tissues obtained from age-matched normal controls (Gibbs and Griffin, 1970). If such a difference occurred also in cultures of human diploid fibroblasts, large numbers of cells could be available for study free from the influences in vivo of the host. $\beta$-Glucuronidase has been investigated previously in fibroblasts, and the specific activity of this mainly lysosomal enzyme shown to vary with the stage of the culture cycle (Gorman, 1963; DeMars, 1964), as occurs with many enzymes (Pan and Krooth, 1968) including some others in the lysosome, eg, arylsulphatase A (Leroy, Dumon, and Radermecker, 1970) and hexosaminidase (Okada et al, 1971). This study was designed to compare the $\beta$-glucuronidase activity in fibroblasts from persons with and without cystic fibrosis during the culture cycle from trypsinization to confluency.

The cells used were derived from punch skin biopsies, and consisted of 3 strains from males with cystic fibrosis and 8 control strains from normals or persons with unrelated disorders. Samples of the strains (which had generally been frozen early in the life-span) were thawed from liquid nitrogen, grown in $60 \mathrm{~mm}$ Falcon tissue culture dishes with medium containing $85 \%$ Eagles MEM (Dulbecco modified) and 15\% fetal calf serum, and subcultured with $0.25 \%$ trypsin in phosphatebuffered saline. For all the growth experiments the cells were inoculated at $5 \times 10^{4}$ cells per dish into either $30 \mathrm{~mm}$ glass dishes, $35 \mathrm{~mm}$ Limbro dishes, or onto $22 \mathrm{~mm}$ coverslips in $35 \mathrm{~mm}$ Limbro dishes. All cultures were rinsed 3 times with $0.9 \%$

Received 22 March 1971.

* This work was supported by USPHS grants AM-13655 and AM-11448 and a USPHS fellowship to S.B.R.

† Present address: Meharry Medical College, 18th Street, Nashville, Tennessee 37215 , USA. saline before disruption, as fetal calf serum may contain some $\beta$-glucuronidase (Gorman, 1963).

The cultures were prepared for assay either by scraping the cells from the dish and disrupting them in 815 -second bursts with a Biosonik probe sonicator, by acetone fixation in situ when glass dishes were used, or by air drying in situ when plastic dishes were employed. In the case of the air-dried samples $0 \cdot 1 \%$ Triton $\mathrm{X}-100$ was added to the reaction mixture; in the case of the sonicated samples the reaction mixture was centrifuged before reading. All assays were measured against a cell-free blank and done in duplicate. There was essentially no difference in activity using the 3 disruption methods.

The activity of $\beta$-glucuronidase was measured according to the method of Gorman (1963). Thus the reaction mixture contained $2 \times 10^{-3} \mathrm{M}$ phenolphthalein $\beta$-glucuronide in $0.1 \mathrm{M}$ acetate buffer at $p \mathrm{H} 5.0$ in a final volume of $0.6 \mathrm{ml}$ whether applied directly to the fixed cells or if sonicated extract was used. Reactions were incubated for 1-8 hrs at $37^{\circ} \mathrm{C}$, and stopped with the development of colour by the addition of $0.6 \mathrm{ml}$ of $1 \mathrm{M}$ glycine buffer at $p \mathrm{H} 10 \cdot 5$. Then the optical density of alkaline phenolphthalein was measured at $555 \mathrm{~m} \mu$ in a $1 \mathrm{ml}$ cuvette with a path length of $1 \mathrm{~cm}$ in a Zeiss spectrophotometer. The optical density multiplied by $44 \cdot 3 / 1000$ gives the $\mu$ moles of glucuronide split (Gorman, 1963); $1 \mu$ mole split per minute equals 1 international unit (IU). Protein determinations were done according to the method of Oyama and Eagle (1956), and cell counts performed in a Model A Coulter counter.

A preliminary experiment was done to scan the general shape of the curve for $\beta$-glucuronidase activity over the culture cycle, and to see if large differences existed between cells from a control and persons with cystic fibrosis. Unexpectedly the cystic fibrosis cells had a higher specific activity 


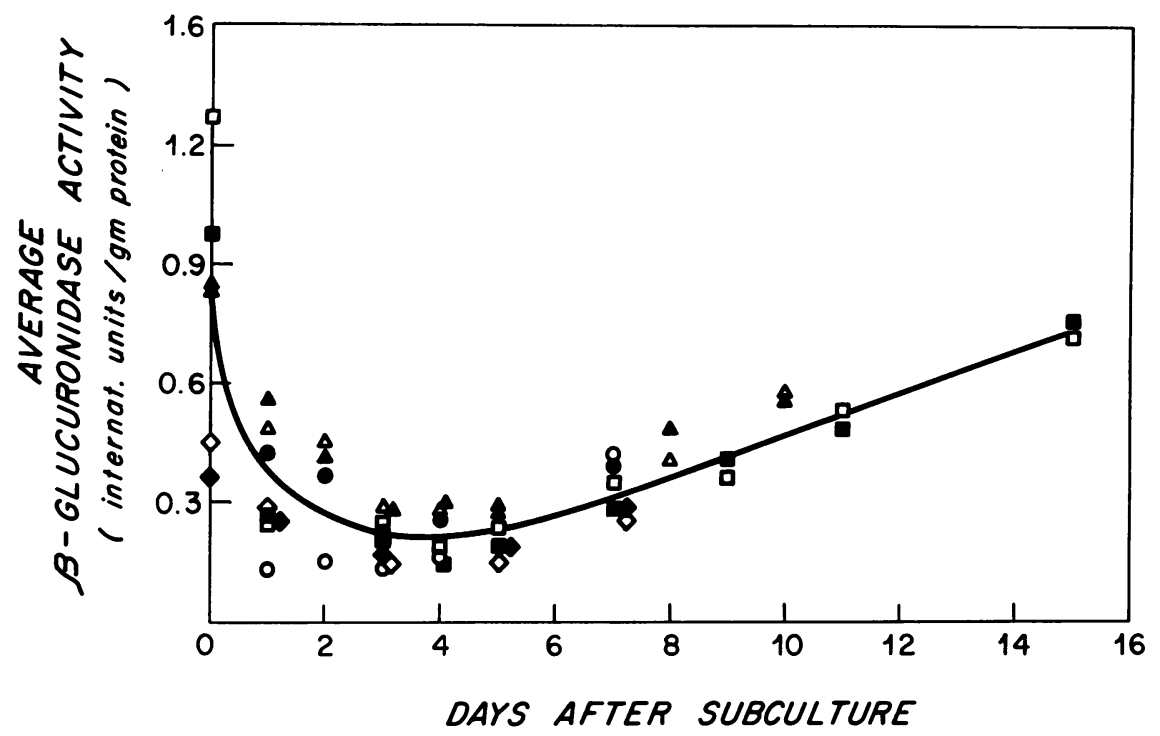

FIg. Changes in the mean specific activities of $\beta$-glucuronidase (IU/g protein) for the cystic fibrosis and control strains for each day of the culture cycle in 4 experiments.

The cystic fibrosis means are represented by symbols $\bullet, \boldsymbol{\square}, \boldsymbol{\Delta}$, and $\bullet$, for experiments $1,2,3$, and 4 respectively, and the control values by symbols $\bigcirc, \square, \triangle$, and $\diamond$, for the same experiments. Experiments 1,2 , and 3 were done with cells from 3 different persons with cystic fibrosis and a normal control. All the stock cultures used to inoculate dishes in experiments 2 and 3 were 17 and 20 days old wespectively. The cystic fibrosis stock cultures in experiment 1 were 10 days old, and the control culture was less than a week old.
rester In experiment 4, 7 additional control lines were used, and all the stock cultures were 6 days old. In all experiments, confluency (stationary phase) was reached between days 6 and 7.

than the normal strain in the early stages of the culture cycle. This difference disappeared by 7 days (experiment 1 in Fig.). However, before this experiment the stock cultures from the cystic fibrosis patients had been confluent for a longer time than had the normal strain. Since it was not known if the initial shape of the curve was dependent on the culture age of the stock, the following experiments were done in such a way that all the cultures had at least one culture cycle of the same duration before being used for the experimental growth cycle. In addition the specific activity of a duplicate stock dish was measured on day 0 before trypsinization. As can be seen in experiments 2,3 , and 4 (Fig.), there was then no difference in the mean specific activity of the cystic fibrosis cells and the control cells at any time during the culture cycle.

These results emphasize that differences in the activity of $\beta$-glucuronidase must be interpreted with great care. They stress that the duration of the previous culture cycle, or some related factor, affects the initial level and subsequent drop in activity of $\beta$-glucuronidase. Other factors known to affect $\beta$-glucuronidase activity in cultured cells include the level of glucuronic acid in the medium (Paul et al, 1964), the occurrence of pinocytosis
(Axline and Cohn, 1970), the content of serum and? conditioning of the medium (Gorman, 1963), and ageing in diploid cells (Cristofalo, 1970). Furthermore the range of activities in cells from different people is quite large (Table) (Gorman, 1963).

TABLE

MEAN AND RANGE OF $\beta$-GLUCURONIDASE ACTIVITIES DURING A CULTURE CYCLE

\begin{tabular}{c|c|c|c|c}
\hline \multirow{2}{*}{ Day } & \multicolumn{2}{|c|}{ Cystic Fibrosis Cells } & \multicolumn{2}{c}{ Control Cells } \\
\cline { 2 - 3 } \cline { 5 - 5 } & Mean & Range & Mean & Range \\
\hline 0 & 0.44 & $0.44-0.45$ & 0.35 & $0.23-0.47$ \\
1 & 0.28 & $0.20-0.30$ & 0.25 & $0.18-0.41$ \\
3 & 0.14 & $0.13-0.15$ & 0.16 & $0.12-0.20$ \\
5 & 0.15 & $0.11-0.17$ & 0.19 & $0.16-0.22$ \\
7 & 0.26 & $0.20-0.34$ & 0.28 & $0.20-0.39$ \\
\hline
\end{tabular}

Activities are expressed as IU/g protein; cells from 8 controls and 3 patients with cystic fibrosis are included.

The drop in the specific activity of $\beta$-glucuronidase (and certain other lysosomal enzymes) following passage of cells is interesting and needs further study. A comparison of the rate of fall when expressed as specific activity and when expressed as enzyme activity per culture (data not presented here) suggests that the drop may actually consist of two components. The first seems a true drop in total enzyme activity, which may relate somehow 
to the effects of trypsinization and dilution of the cells on this particular enzyme or lysosomes in general. Subsequently specific activity continues to drop, but the total enzyme activity per culture remains constant. This suggests that the lag phase for synthesis of $\beta$-glucuronidase is longer than the lag phase for that of other cell proteins. Conversely, in the stationary phase it appears that $\beta$-glucuronidase is being formed later than most other proteins (Gorman, 1963), perhaps related to an increase in the number of lysosomes (Comings and Okada, 1970). Finally it is worth emphasizing that another enzyme at least partly of lysosomal origin (acid phosphatase) behaves quite differently from $\beta$-glucuronidase in the various features described above (DeMars, 1964).

\section{Summary}

$\beta$-Glucuronidase activity was determined over the culture cycle of human diploid fibroblasts in order to compare the activity in cells from persons with cystic fibrosis and from persons not affected with this disease. When the stock cultures for these experiments were handled identically, there was no difference between the two categories of cells at any time studied. Because the specific activity of this enzyme changes over the culture cycle, cells must be compared at the same stage of the cycle to avoid artefactual differences.

\section{REFERENCES}

Axline, S. G. and Cohn, Z. A. (1970). In vitro induction of lysosomal enzymes by phagocytosis. Fournal of Experimental Medicine, 131, 1239-1260.

Comings, D. E. and Okada, T. A. (1970). Electron microscopy of human fibroblasts in tissue culture during logarithmic and confluent stages of growth. Experimental Cell Research, 61, 295-301.

Cristofalo, V. J. (1970). Metabolic aspects of aging in diploid human cells. In Aging in Cell and Tissue Culture, edited by E. Holeckova and V. J. Cristofalo, pp. 83-119. Plenum Press, New York.

DeMars, R. (1964). Some studies of enzymes in cultivated human cells. National Cancer Institute Monograph, 13, 181-195.

Gibbs, G. E. and Griffin, G. D. (1970). $\beta$-glucuronidase activity in skin components of children with cystic fibrosis. Science, 167 , 993-994.

Gorman, J. A. (1963). $\beta$-Glucuronidase Activity in Cultivated Human Cells. PhD Thesis, Wisconsin.

Leroy, J. G., Damon, J., and Radermecker, J. (1970). Deficiency of arylsulphatase $\mathbf{A}$ in leukocytes and skin fibroblasts in juvenile metachromatic leucodystrophy. Nature, 226, 553-554.

Okada, S., Veath, M. L., Leroy, J., and O'Brien, J. S. (1971). Ganglioside $\mathrm{G}_{2}$ storage diseases: hexosaminidase deficiencies in cultured fibroblasts. American fournal of Human Genetics, 23, $55-61$.

Oyama, V. I. and Eagle, H. (1956). Measurements of cell growth in tissue culture with a phenol reagent (Folin-Ciocalteau). Proceedings of the Society for Experimental Biology and Medicine, 91, 305-307.

Pan, Y.-L. and Krooth, R. S. (1968). The influence of progressive growth on the specific catalase activity of human diploid cell strains. Fournal of Cellular Physiology, 71, 151-160.

Paul, J., Fottrell, P. F., Freshney, I., Jondorf, W. R., and Struthers, M. G. (1964). Regulation of enzyme synthesis in cultured cells. National Cancer Institute Monograph, 13, 219-228. 